\title{
The Analysis of the U.S. Financial Year (FY) 2014 Defense Budget ${ }^{1}$
}

\author{
SZABÓ Albert ${ }^{2}$
}

\section{Introduction}

The analysis examines the governmental decisions that tried to provide alternatives and offer a realistic response to the current U.S. debt crisis, severely undermining those defense budget provisions that had previously been planned. First, the impact of the 2011 Budget Control Act and the 'sequestration' process will be examined within the context of U.S. defense planning, giving a comprehensive overview of the U.S. budget debate with regard to U.S defense policy. Then the analysis compares and contrasts the current 2013 financial year data to the 2014 financial plan proposal based on President Obama's statement in the White House on April 10, 2013, in which he presented the key points of the 2014 financial year budget. There the President put an emphasis on his sustained effort to improve the situation of American people through social benefit programs. These will have a determining effect to the United States armed forces in the future, which operate under heavy pressure and at times financial austerity. Expenses of social welfare and medical care are important for our analysis, as these belong to more steady mandatory items of the federal budget, while the defense budget relies mostly on discretionary funding, and is subject to major fluctuations. Finally the assessment will reflect on the Obama administration's FY 2014 proposals with regard to the US defense policy review process in order to highlight the practical effects of sequestration.

Keywords: United States, strategy, defense policy, sequestration, financing

\section{The essence of the Budget Control Act and the sequestration process}

President Barack Obama approved the Budget Control Act (BCA) [1] on August 2 2011. In several aspects this was a milestone in the history of the United States, as one of the worst budget crises ever was postponed by the Act. Enacting the BCA was the only way for the United States to maintain financial liquidity in the short term. Even though it has never happened in U.S. history that the financial year has closed with a budget surplus, but this particular situation was extremely hard: enduring fiscal deficit and the continuously high stock of government debt was to continue increasing the debt accumulation in the U.S., paralyzing financial policy. Therefore, significant fiscal spending cuts were enacted to regulate the growth of debt and maintain financial viability.

1 This article is the written form of the presentation that was shown on the Central European Forum on Higher Military Education (CEFME) International Young Scientists Conference on December 2013, NUPS, Budapest 
The BCA created the so called Joint Select Committee on Deficit Reduction, publicly referred to as the Super Committee, whose primary task was finding a suitable solution to reduce the estimated \$ 1.2 trillion deficit over the next ten years. However, in the selected ten-year period, the BCA will be followed much more by rebalancing the rate of debt accumulation, raising again long-disputed questions within U.S. politics, like how these cuts would be distributed among the different departments and functional fields.

As the next step, the budget sequestration process was initiated as an inevitable measure, unless a negotiated solution to executing budget reductions was found. The budget sequestration in 2013 referred to the automatic spending cuts of U.S. federal government spending in different categories of outlays that were initially set to go into effect on January 1, 2013. Both parties in Congress, the President, and the secretary of defense insisted that sequestration would not be allowed to go into effect, and no contingency plans were developed to mitigate the effects. Despite being under serious pressure, sequestration was also postponed by a further two months by the American Taxpayer Relief Act of 2012, until March $1^{\text {st }} 2013$ to create further opportunity for a bipartisan negotiated solution. However, still lacking consensus the sequestration finally went into effect. The sequestration became a major topic of the fiscal cliff debate. The debate's resolution, the American Taxpayer Relief Act of 2012 (ATRA), [2] eliminated much of the taxation issues of the dispute but only delayed budget sequestrations for two months, thus reducing the original \$110 billion to be saved per fiscal year to \$85 billion in 2013. [3] The reductions in spending authority are approximately $\$ 85.4$ billion during fiscal year 2013, with similar cuts for years 2014 through 2021. [4] However, the Congressional Budget Office estimated that the total federal outlays will continue to increase even with the sequester by an average of $\$ 238.6$ billion per year during the next decade, although at a somewhat lesser rate.

\section{Historical perspectives}

Putting the uneasy situation of the U.S federal budget crisis into historical perspective and contrasting the Department of Defense (DoD) budget within, we can observe unprecedented levels of DoD expenditure in real terms, explaining a lot about the current crisis. On February $1^{\text {st }}$ 2011, the Obama administration released its FY 2011 budget. That fiscal year was seeking 549 billion dollars for the Department of Defense base budget, which also included war costs. This represents a nominal increase of 2.8 percent in real terms, or 1.4 percent over the FY 2010 request.

Since 2001, the base budget has grown by an average of four percent per year above inflation. Overall funding for overseas contingency operations (OCO) has declined by just over 50 percent since 2008 when the war in Iraq ended. [5] 


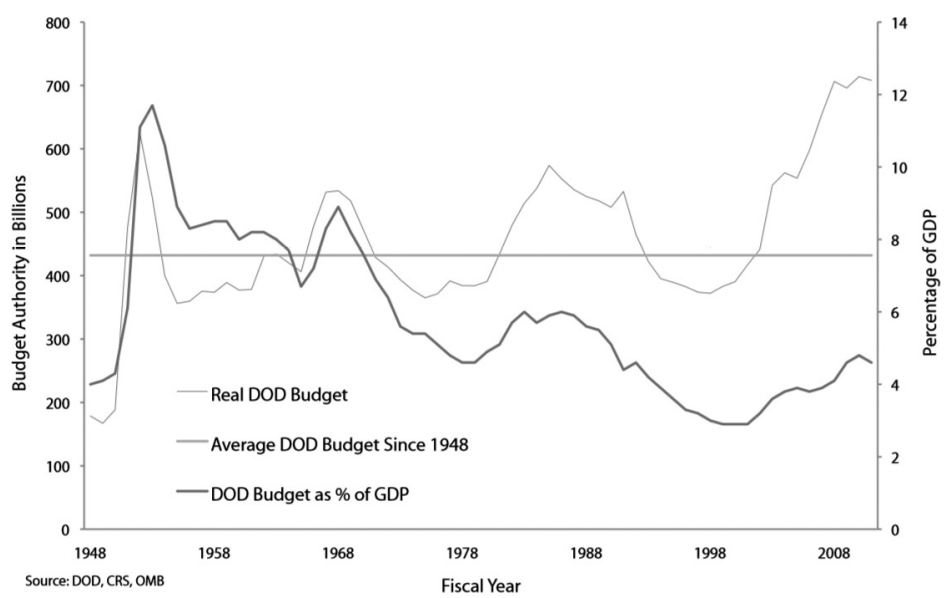

Chart 1. Pentagon Budget Since 1948 [6]

(in constant FY 2011 dollars - includes war costs)

As Chart 1 shows, defense spending since World War II has risen and fallen in cycles. In inflation-adjusted dollars and including war costs, the FY 2011 Pentagon budget request was 13 percent higher than the Korea War peak, summing up to 624 billion dollars; and it was 33 percent higher than the Vietnam War peak (534 billion dollars), 23 percent higher than the Reagan-era 1980s peak (574 billion dollars), and 64 percent higher than the Cold War average (432 billion dollars), and also 15 percent higher than the post-9/11 average which was 618 billion dollars. The latter symbolized the historic DoD budget record in the United States.

\section{Effects on the FY 2014 defense budget}

Our intention is to compare the FY 2013 defense budget to the FY 2014 defense budget request and to examine the main fracture points which influence U.S defense policy planning. The Obama Administration requested \$525.4 billion in discretionary funding and \$6.3 billion in mandatory funding in the base Department of Defense budget for FY 2013. Initially the budget did not include a request for Overseas Contingency Operations (OCO) funding and instead used a placeholder of $\$ 88.5$ billion, which was similar to the level of war funding in FY 2012. In May, the DoD released its FY 2014 OCO budget request, which totaled $\$ 88.5$ billion. With this change, the total DoD request for FY 2013 — including the base budget and OCO — was set to $\$ 620.2$ billion USD. 


\begin{tabular}{lc}
\hline Account & $\begin{array}{c}\text { FY 2013 Request } \\
\text { (in billions) }\end{array}$ \\
\hline DoD Base Discretionary & $\$ 525.4$ \\
DoD Base Mandatory & $\$ 6.3$ \\
DoD Overseas Contingency Operations & $\$ 88.5$ \\
DoD Total (051) & $\$ 620.2$ \\
& $\$ 17.8$ \\
Department of Energy & $\$ 1.4$ \\
Department of Labor & $\$ 0.2$ \\
Other Agencies & $\$ 19.4$ \\
Atomic Energy Total (053) & $\$ 4.8$ \\
& $\$ 1.6$ \\
Department of Justice & $\$ 1.4$ \\
Department of Homeland Security & $\$ 7.7$ \\
Other Agencies & $\$ 137.4$ \\
Defense-Related Activities Total (054) & $\$ 0.4$ \\
Department of Veterans Affairs & $\$ 137.7$ \\
Other Agencies & $\$ 67.2$ \\
Veterans Total (700) & \\
Payment to Military Retirement Fund & $\$ 852.2$ \\
\hline
\end{tabular}

Chart 2. Summary of defense-related funding in the FY 2013 Budget Request [7]

Chart 2 presents the total defense-related budget that includes more than the DoD budget alone. The budget request also includes \$19.4 billion for defense-related atomic energy programs, $\$ 7.7$ billion for defense-related activities in other agencies, and $\$ 137.7$ billion for veterans' benefits and services. The treasury must also make an annual payment of $\$ 67.2$ billion to the Military Retirement Trust Fund which was $\$ 15.2$ billion. Together these expenses total $\$ 852.2$ billion, or 23 percent of the total federal budget.

The FY 2014 budget request was released by the Obama administration on April 10 and this request - similarly to the FY 2013 defense request — does not comply with the Budget Control Act budget caps currently in effect for FY 2014, exceeding the caps by \$52 billion. The FY 2014 budget requests a total of $\$ 612.5$ billion for the Department of Defense (DoD). The base budget for the Department includes $\$ 526.6$ billion in discretionary funding and $\$ 6.5$ billion in mandatory funding. An additional $\$ 79.4$ billion is requested for ongoing military operations, primarily in Afghanistan. 


\begin{tabular}{lc}
\hline Account & $\begin{array}{c}\text { FY 2014 Request } \\
\text { (in billions) }\end{array}$ \\
\hline DoD Base (discretionary) & $\$ 526.6$ \\
DoD Base (mandatory) & $\$ 6.5$ \\
DoD Overseas Contingency Operations & $\$ 79.4$ \\
DoD Total (051) & $\$ 612.5$ \\
& \\
Department of Energy & $\$ 17.8$ \\
Department of Labor & $\$ 1.3$ \\
Other Agencies & $\$ 0.2$ \\
Atomic Energy Total (053) & $\$ 19.3$ \\
& \\
Department of Justice & $\$ 5.0$ \\
Department of Homeland Security & $\$ 1.6$ \\
Other Agencies & $\$ 1.4$ \\
Defense-Related Activities Total (054) & $\$ 8.0$ \\
& \\
Department of Veterans Affairs (discretionary) & $\$ 63.5$ \\
Department of Veterans Affairs (mandatory) & $\$ 86.1$ \\
Other Agencies & $\$ 0.4$ \\
Veterans Total (700) & $\$ 150.0$ \\
Treasury Payment to the Military Retirement Trust & $\$ 70.3$ \\
Tax Exemptions for Military Personnel & $\$ 15.2$ \\
Other Total & $\$ 85.4$ \\
Total Defense-Related Spending & $\$ 875.2$ \\
\hline
\end{tabular}

Chart 3. Summary of Defense-related Funding in the FY 2013 Budget Request [8]

The total defense-related budget request also includes $\$ 19.3$ billion for defense-related atomic energy programs; $\$ 7.7$ billion for defense-related activities in other agencies; $\$ 137.7$ billion for veterans’ benefits and services; $\$ 70.3$ billion to the Military Retirement Trust Fund to cover unfunded obligations from prior years, as well as tax exemptions for military personnel that resulted in $\$ 15.2$ billion in lost revenue. Altogether these expenses total $\$ 875.2$ billion, which is nearly a quarter of the total federal budget.

Nonetheless, when comparing the total FY 2014 department of defense base budget request with the previous year we find that it had been reduced by $\$ 7.7$ billion on the one hand, but on the other the total defense related spending had been increased by 23 billion dollars. The reason for this increase in spending is veterans' benefits and services, plus the costs of the military retirement trust fund. If we add up all these extra costs the result is $\$ 235.4$ billion which is nearly half of the base DoD budget, or 'it could cover the costs of three Afghanistan wars'.

The 2012 Defense Strategic Guidance [9] calls for rebalancing to the Pacific region and the Middle East. The U.S. military is not likely to emerge from this drawdown with the capacity or capability to both increase its presence in the Asia-Pacific region and maintain its current level of presence in the Middle East. As the FY 2014 budget request also shows, U.S. forces can be redeployed from one theater to another as needed in the event of a conflict, but the military may not be able to address successfully two major overlapping conflicts in different theaters. 


\section{Conclusion}

Basically, the fiscal uncertainty that began in 2011 with the federal statute of the BCA has only grown worse over time with the throw-back of the Super Committee, sequestration going into effect, and the government shutdown. Now that sequestration has indeed begun and the sharpest decrease from FY 2012 to FY 2013 has already taken place, the BCA budget caps may be more of a ceiling than floor in the coming years. Moreover, a significant reduction in the defense budget means that the United States will have to make a number of critical strategic choices in defense planning and management for the future. [8] The sequestration process or the BCA do not relieve defense planners from making these difficult choices because future funding levels are never certain-Congress only appropriates one year at a time. [10]

Finally, the current budget impasse may not be resolved until the Afghanistan drawdown is effectively over, at which point many of the critical decisions will have already been made for the Defense Department by incremental reductions that chip away at programs yearby-year or, worse, by the blunt and indiscriminant mechanism of sequestration. The 2014 Quadrennial Defense Review (QDR) and the FY 2015 budget request will provide an opportunity for the Defense Department to address the rapidly evolving budgetary pressure. If the Department plans for the reduced budget caps in its FY 2015 request and uses the QDR as an opportunity to alter its strategic guidance according to these more realistic budget constraints, it will give DoD greater say in how cuts are implemented in the future but on the other hand this approach is not without risks. [11] The Department now has an opportunity to revise its budget and strategic guidance to fit within more realistic resource constraints.

\section{References}

[1] Budget Control Act of 2011, One Hundred Twelfth Congress of the United States of America. Washington, D.C.: U. S. Government Printing Office, 2012. http://www.gpo.gov/fdsys/pkg/ BILLS-112s365enr/pdf/BILLS-112s365enr.pdf (downloaded: 2811 2013)

[2] The American Taxpayer Relief Act of 2012. Washington, D.C.: U. S. Government Printing Office, 2013. http://www.gpo.gov/fdsys/pkg/BILLS-112hr8eas/pdf/BILLS-112hr8eas.pdf (downloaded: 2811 2013)

[3] HOOK, J., BOLES, C., HUGHES, S.: Congress Passes Cliff Deal. The Wall Street Journal, 0201 2013. http://online.wsj.com/news/articles/SB10001424127887323 320404578215373352793876?mg=reno64-wsj\&url=http\%3A\%2F\%2Fonline.wsj. com\%2Farticle\%2FSB10001424127887323320404578 (downloaded: 112 2013)

[4] Summary of the DoD Fiscal Year 2014 Budget Proposal. Washington, D.C.: U.S. Department of Defense, 2014. http://www.defense.gov/news/2014budget.pdf (downloaded: 2602 2014)

[5] WALKER, D.: Trends in U.S. Military Spending. Council on Foreign Relations, 30072013. http://www.cfr.org/defense-budget/trends-us-military-spending/p28855 (downloaded: 2602 2013)

[6] SHARP, T.: Chart 3: Pentagon Budget since 1948. In. Vision Meets Reality: 2010 QDR and 2011 Defense Budget. Center for a New American Security, 2010. http://www.cnas.org/files/ documents/publications/2011DefenseBudget_Sharp_Feb2010_code904_policybrf_0.pdf (downloaded: 212 2013) 
[7] HARRISON, T.: Analysis of the FY 2013 Defense Budget and Sequestration. Washington, D.C.: Center for Strategic-Budgetary Assessment, 2012. http://www.csbaonline. org/publications/2012/08/analysis-of-the-fy2013-defense-budget-and-sequestration/ (downloaded: 2712 2013)

[8] HARRISON, T.: Chaos and Uncertainty: The FY 2014 Defense Budget and Beyond. Washington, D.C.: Center for Strategic-Budgetary Assessment, 2013. http://www. csbaonline.org/publications/2013/10/chaos-and-uncertainty-the-fy-14-defense-budget-andbeyond/ (downloaded: 2812 2013)

[9] Sustaining U.S. Global Leadership: Priorities for $21^{\text {st }}$ Century Defense. Washington, D.C: The White House, 2012. (This guidance, nonetheless, was issued before sequestration went into effect, because it was imposed in 2012 January 3. http://www.defense.gov/news/ defense_strategic_guidance.pdf. (downloaded: 1611 2014)

[10] CARROLL, C.: Army budget fall slightly, as does end strength. Washington, D.C.: Stars and Stripes, 2013. http://www.stripes.com/army-budgets-fall-slightly-as-does-endstrength-1.216020 (downloaded: 1311 2013)

[11] MURDOK, C.: Preparing for the 2014 Quadrennial Defense Review. Conference Proceedings, Presentations, and Key Takeaway. Washington, D.C.: Center for Strategic \& International Studies, 2013. http://csis.org/files/publication/130319_Murdock_ Preparing2014QDR_Web.pdf (downloaded: 1202 2014) 